Hanna Sikacz

Uniwersytet Ekonomiczny we Wrockawiu

Przemyslaw Wolczek

Uniwersytet Ekonomiczny we Wroctawiu

\title{
Analiza ESG spólek z indeksu RESPECT na podstawie bazy ASSET4 ESG
}

\author{
ESG ANALYSIS OF COMPANIES INCLUDED IN THE \\ RESPECT INDEX BASED ON ASSET4 ESG DATABASE
}

Niniejsze opracowanie dotyczy analizy danych niefinansowych zwiazanych z kwestiami ochrony środowiska, odpowiedzialności społecznej i ładu organizacyjnego zwanych danymi ESG (ang. Environmental, Social, Governance). Przedmiotem analizy sq spótki wchodzace w sktad indeksu RESPECT, co sugeruje, że ich wyniki ESG powinny być wysokie z racji przynależności do tego indeksu. Celem opracowania jest zatem zweryfikowanie pogladu dotyczqcego wysokich wyników ESG spółek z indeksu RESPECT. Do analizy wykorzystano dane z bazy ASSET4 ESG firmowanej przez Thomson Reuters, jednego z glównych światowych dostawców informacji, zarówno dla przedsiębiorstw, specjalistów, jak i naukowców. Zaprezentowana analiza wyników ESG uzyskanych przez spótki wchodzqce w skład indeksu RESPECT wskazuje na duże różnice w wynikach między danymi podmiotami, mimo że po spótkach majacych spetniać najwyższe standardy zwiqzane z odpowiedzialnościq można było spodziewać się mniejszych różnic i lepszych rezultatów.

Słowa kluczowe: czynniki ESG, RESPECT Index, ASSET4 ESG, bazy danych ESG

\section{Wprowadzenie}

Dane finansowe już nie wystarczają do oceny wyników przedsiębiorstwa, a zwłaszcza jego możliwości i potencjału. Kompleksowa, rzetelnie przeprowadzona ocena przedsiębiorstwa zawiera już nie tylko wskaźniki ekonomiczne i finansowe, ale także dane środowiskowe, społeczne oraz dotyczące ładu organizacyjnego. W sytuacji istotnego oddziaływania przedsiębiorstwa na środowisko duże znaczenie mają kwestie związane raportowaniem przez przedsiębiorstwo informacji na temat tego oddziaływania. Niezależnie od sektora, które reprezentuje przedsiębiorstwo, kwestie społeczne związane z pracownikami, warunkami ich zatrudnienia, szkoleniami, bezpieczeństwem i higieną pracy, możliwościami rozwoju są równie ważne. Nie inaczej ma się sprawa kwestii dotyczących ładu organizacyjnego. Dla interesariuszy, a zwłaszcza dla inwestorów, ważne jest czy przedsiębiorstwo posiada w swojej strukturze odpowiednie komórki zajmujące się m.in. sprawami audytu, wynagrodzeń, polityki różnorodności, zagadnieniami zrównoważonego rozwoju/CSR ${ }^{1}$ czy też raportowania finansowego i niefinansowego.

${ }^{1}$ CSR - społeczna odpowiedzialność przedsiębiorstwa (ang. Corporate Social Responsibility). 
Niniejsze opracowanie dotyczy analizy danych niefinansowych związanych $\mathrm{z}$ kwestiami ochrony środowiska, odpowiedzialności społecznej i ładu organizacyjnego zwanych danymi ESG (ang. Environmetal, Social, Governance, ESG). Przedmiotem analizy są spółki wchodzące w skład indeksu RESPECT, co sugeruje, że ich wyniki ESG powinny być wysokie $\mathrm{z}$ racji przynależności do tego indeksu. Indeks RESPECT $\mathrm{z}$ założenia bowiem powinien składać się ze spółek, które w najwyższym stopniu spełniają wymagania w zakresie ładu organizacyjnego, ładu informacyjnego i relacji z inwestorami, a przede wszystkim wypełniają szereg wymagań zaliczanych do grupy czynników środowiskowych, społecznej odpowiedzialności i ładu organizacyjnego.

Celem opracowania jest zatem zweryfikowanie poglądu dotyczącego wysokich wyników ESG spółek z indeksu RESPECT. Do analizy wykorzystano dane z bazy ASSET4 ESG firmowanej przez Thomson Reuters, jednego z głównych światowych dostawców informacji, zarówno dla przedsiębiorstw, specjalistów, jak i naukowców.

\section{Znaczenie kwestii ESG}

Coraz więcej spółek decyduje się na publikację raportów z danymi niefinansowymi lub raportów zintegrowanych, w których znajdują się dane zarówno finansowe, jak i niefinansowe. W Stanach Zjednoczonych i Europie Zachodniej uwzględnianie danych niefinansowych przez inwestorów w procesie inwestycyjnym już teraz jest standardem [Sroka 2016, s. 51]. Potwierdzeniem zachodzących zmian związanych z postrzeganiem komponentów decydujących o wartości spółek są na przykład badania Ocena Tomo LLC. W 1975 roku o wartości indeksu S\&P 500 w 83\% decydowały aktywa materiale. Natomiast w 2015 roku o wartości indeksu w 84\% decydowały aktywa niematerialne [Ocena Tomo LLC 2015]. Obserwowany trend wpływa na wzrost znaczenia uwzględniania w działalności podmiotów kwestii ESG i informowania otoczenia (interesariuszy) o działaniach $\mathrm{w}$ ramach tych obszarów.

Problematyka czynników ESG podejmowana jest przede wszystkim w kontekście odpowiedzialnego inwestowania (ang. Socially Responsible Investing, SRI), analizy ESG spółek, rozwoju zrównoważonego i społecznej odpowiedzialności przedsiębiorstwa oraz raportowania informacji niefinansowych.

Działania w obszarze związanym ze środowiskiem, społeczeństwem i ładem organizacyjnym należy wiązać m.in. z:

- budowaniem wartości przedsiębiorstwa [Domańska-Szaruga B., 2011, s. 141-151],

- budową portfela w ramach inwestycji społecznie odpowiedzialnych [Marcinkowska 2010, s. 124],

- kwestiami związanymi z niższym kosztem kapitału [Bassen i in. 2006],

- lepszym wizerunkiem i zaufaniem do spółki [Sroka 2014, s. 46],

- większą innowacyjnością [Burke, Logsdon 1996, s. 500],

- lepszym zarządzeniem ryzykiem w przedsiębiorstwie w przypadku dodatkowego uwzględniania ryzyk związanych z wpływem na środowisko czy w obszarze społecznym [Jędrzejka 2014, s. 14],

- redukcją zużycia zasobów [Jędrzejka 2014, s. 14],

- lepszą postawą pracowników wobec przedsiębiorstwa [Knox, Maklan 2004, s. 2529; Burke, Logsdon 1996, s. 500; Maignan, Ferrell 2001, s. 39-40], 
- demonstracją zdolności podmiotu do uczestnictwa w konkurencyjnych rynkach [Kaputa 2013, s. 116].

Większa przejrzystość spółek pozwala na podejmowanie bardziej racjonalnych decyzji inwestycyjnych [Sroka, 2012, s. 8]. Można zatem spodziewać się, że zapotrzebowanie na dane ESG będzie nadal rosnąć, a baza $\mathrm{z}$ danymi, taka jak ASSET4 ESG, może pomóc inwestorom w podejmowaniu decyzji inwestycyjnych [Ribando J.M., Bonne G. 2010,s. 8].

\section{ASSET4 ESG Data - podstawowe informacje o bazie}

Baza danych ASSET4 ESG Data zapewnia dostęp do szczegółowych, obiektywnych, aktualnych i porównywalnych danych ESG. Ponadto uwzględnia negatywne i kontrowersyjne informacje o przedsiębiorstwach publikowane $\mathrm{w}$ różnych globalnych mediach. W bazie tej znajdziemy m.in. [Thomson Reuters 2012a, 2012b]:

- dane ESG ponad 4300 przedsiębiorstw,

- ponad 750 danych cząstkowych raportowanych w ramach rozwoju zrównoważonego,

- ponad $280 \mathrm{KPI}$ (ang. key performacne indicators),

- historię danych od 2002 r. ponad 1000 przedsiębiorstw,

- dane pochodzacee z takich indeksów jak: MSCI World, MSCI Europe, STOXX 600, NASDAQ 100, Russell 1000, S\&P 500, FTSE 100, ASX 300, MSCI Emerging Market.

Wyniki ESG przedsiębiorstw ujętych w bazie ASSET4 ESG są aktualizowane co dwa tygodnie $w$ celu odzwierciedlenia najnowszych danych ESG i powiązanych $z$ nimi kontrowersyjnych informacji pojawiających się w globalnych mediach, które dotyczą dowolnej firmy na świecie. Do oceny ESG przedsiębiorstw wykorzystuje się jedynie publicznie dostępne informacje, tak jak np. raporty roczne spółek, materiały dostępne na stronach internetowych organizacji pozarządowych, raporty CSR przedsiębiorstw.

Jak widać na rysunku 1 ocena ważona uwzględnia finansowe i niefinansowe informacje o przedsiębiorstwie na podstawie danych ekonomicznych, środowiskowych, społecznych i dotyczacych ładu organizacyjnego zgromadzonych w bazie ASSET4. Wskaźnik odzwierciedla zrównoważony obraz wyników przedsiębiorstwa w tych czterech obszarach. Jak wskazuje opis bazy ASSET4 ESG uwzględnianie są także wyniki ekonomiczne przedsiębiorstw, na które należy zwrócić uwagę w związku z rozszerzeniem zakresu danych poza tylko ESG. W obszarze ekonomicznym mierzona jest zdolność przedsiębiorstwa do generowania trwałego wzrostu i wysokiego zwrotu z inwestycji dzięki efektywnemu wykorzystaniu wszystkich zasobów. Jest to odzwierciedlenie ogólnej kondycji finansowej podmiotu i jego zdolności do generowania długoterminowej wartości dla akcjonariuszy poprzez wykorzystanie najlepszych praktyk zarządzania.

Na rysunku 1 przedstawiono schemat podziału danych ESG w bazie ASSET4 ESG. 


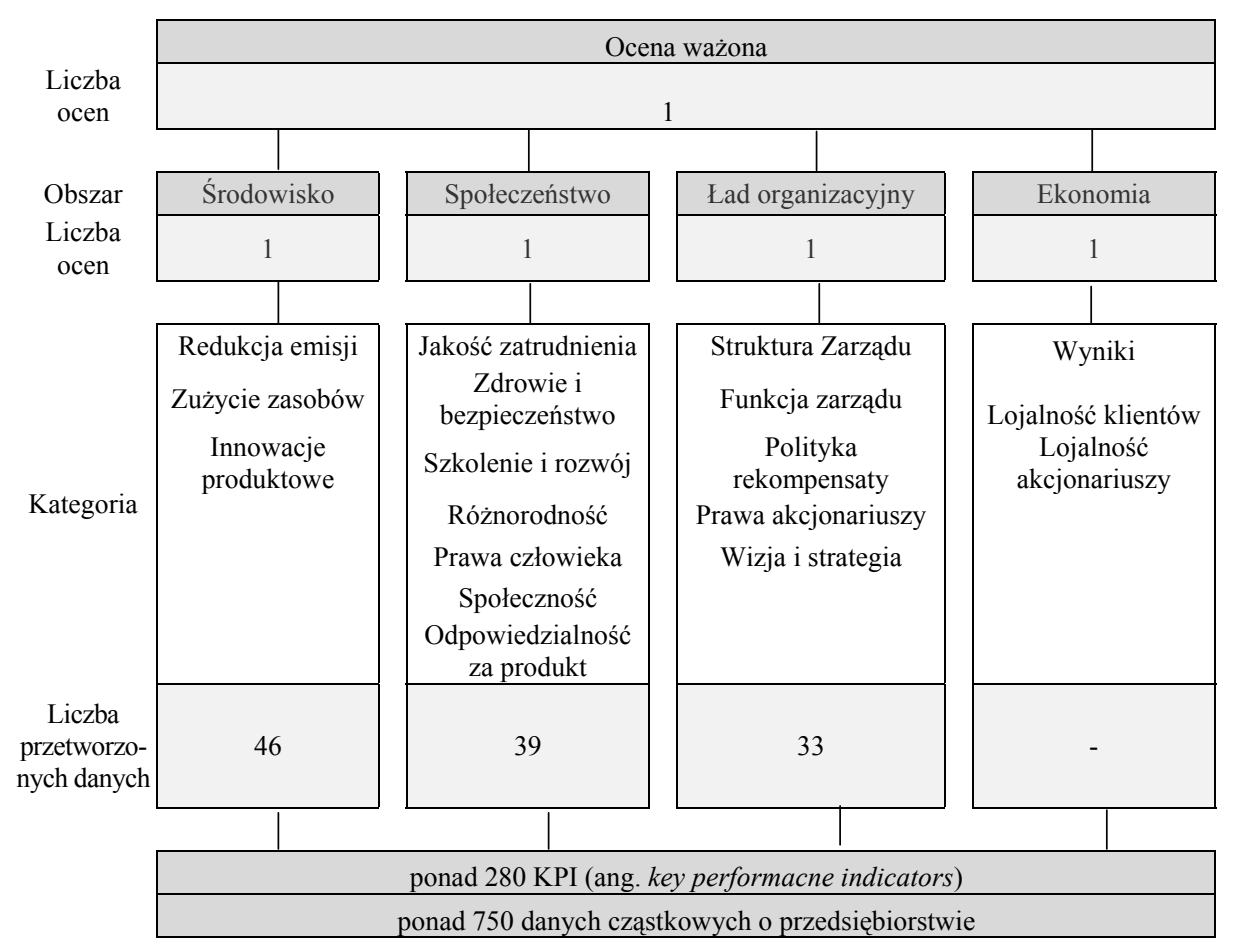

Rysunek 1. Ogólny schemat podziału danych ESG w bazie ASSET4 ESG

Źródło: opracowanie własne na podstawie [Thomson Reuters 2012a, s. 1; 2012b, s. 1].

W tabeli 1 zaprezentowano przykładowe dane, które są brane pod uwagę przy ocenie ESG przedsiębiorstw.

Tabela 1. Przykłady danych branych pod uwagę do oceny spółek na podstawie bazy ASSET4 ESG

\begin{tabular}{|l|l|l|}
\hline \multicolumn{1}{|c|}{ Środowisko } & \multicolumn{1}{|c|}{ Społeczeństwo } & \multicolumn{1}{c|}{ Ład korporacyjny } \\
\hline Redukcja emisji & Jakość zatrudnienia & Średnia liczba lat pracy w \\
Emisja CO2 & Zadowolenie z pracy & zarządzie \\
Redukcja CO2 & Wynagrodzenie & Liczba członków zarządu \\
Redukcja emisji NOx i SOx & Plan premiowy dla pracowników & Różnorodność w organach \\
Emisje NOx & Przedstawicielstwo Związków & zarządzających (\% kobiet) \\
Emisje SOx & Zawodowych & Liczba posiedzeń zarządu \\
Odpady razem & Całkowita liczba urazów & Wynagrodzenie dla kadry \\
Odpady niebezpieczne & Program HIV-AIDS & kierowniczej w dłuższej \\
Współczynnik recyklingu & Średnia liczba godzin szkolenia dla & perspektywie \\
odpadów & każdego pracownika & Prawa akcjonariuszy \\
Emisja zanieczyszczeń z wody & Koszty szkolenia ogółem & Struktura zarządu \\
Zrównoważony transport & Szkolenie w zakresie zarządzania & Komitet ds. rozwoju \\
Nakłady na ochronę środowiska & Systemy zarzaddzania kryzysowego & zrównoważonego (CSR) \\
Całkowite zużycie energii & Satysfakcja konsumenta & Wytyczne do raportowania GRI \\
Produkcja energii weglowych & Dostęp do produktu niska cena & Audyt zewnétrzny raportu CSR \\
Produkcja energii z gazu & & (rozwoju zrównoważonego) \\
ziemnego & & \\
\hline
\end{tabular}




\begin{tabular}{|l|l|l|}
\hline Produkcja energii elektrycznej & & \\
Wykorzystanie energii & & \\
odnawialnej & & \\
Zielone budynki & & \\
Polityka oszczędności wody & & \\
Zużycie wody ogółem & \\
Woda z recyklingu & \\
Redukcja zużycia energii & & \\
Wydatki na badania i rozwój w & & \\
dziedzinie środowiska & \\
Technologie wodne & \\
\hline Źódło: opracowanie własne & \\
\hline
\end{tabular}

Źródło: opracowanie własne.

Liczba danych z trzech obszarów zaprezentowanych tabeli 1, które są brane pod uwage do oceny spółek w bazie ASSET4 ESG, jest dość znacząca. Obejmuje bowiem 118 danych (stąd w tabeli zaprezentowano tylko wybrane dane). Na podstawie tych danych dokonywana jest ocena zarządzania obszarami ESG w przedsiębiorstwie. Dodatkowym obszarem branym pod uwagę do ostatecznej oceny ESG danego podmiotu jest obszar „ekonomia”. Na podstawie bazy ASSET4 ESG uzyskujemy jedynie ostateczny wynik w tym obszarze (brak jest szczegółowych danych składających się na wynik w obszarze „ekonomia”). Wyniki z czterech obszarów dają podstawę do uzyskania wyniku końcowego ESG dla podmiotu.

\section{Metoda i wyniki badań}

Podstawą analizy ESG spółek należących do indeksu RESPECT, których wyniki powinny potwierdzać ich wysoki poziom odpowiedzialności za społeczeństwo i środowisko, a także ponadprzeciętne stosowanie zasad ładu organizacyjnego, było zebranie danych $\mathrm{z}$ bazy ASSET4 ESG.

W skład indeksu RESPECT wchodzą 24 spółki ${ }^{2}$, Zamiarem autorów badania było zebranie danych ESG z bazy ASSET4 ESG dla wszystkich 24 spółek. Wyniki ESG dla jedenastu spółek należących do indeksu RESPECT przedstawione są w tabeli 2. Brak danych w bazie ASSET4 ESG w przypadku pozostałych trzynastu spółek uniemożliwia ocenę ich sytuacji w określonym zakresie. Dane przedstawione w tabeli uszeregowane są w kolejności od najwyższej do najniższej oceny ważonej będącej oceną końcową po uwzględnieniu czterech analizowanych obszarów. Przedstawione zebrane dane dotyczą głównie 2015 r., a w dwóch przypadkach 2016 r. (najbardziej aktualne dane zgodnie ze stanem z 30.06.2017 r.).

Tabela 2. Wyniki ESG dla spółek z RESPECT Index na podstawie bazy ASSET4 ESG

\begin{tabular}{|l|c|c|c|c|c|c|c|}
\hline \multicolumn{1}{|c|}{ Spółka } & Rok & $\begin{array}{c}\text { Środowi- } \\
\text { sko }\end{array}$ & $\begin{array}{c}\text { Społeczeń- } \\
\text { stwo }\end{array}$ & $\begin{array}{c}\text { Ład organiza- } \\
\text { cyjny }\end{array}$ & Ekonomia & $\begin{array}{c}\text { Ocena } \\
\text { ważona }\end{array}$ & $\begin{array}{c}\text { Transpa- } \\
\text { rentność* }\end{array}$ \\
\hline $\begin{array}{l}\text { PKN Orlen S.A. } \\
\begin{array}{l}\text { Bank Zachodni } \\
\text { WBK S.A. }\end{array}\end{array}$ & 2015 & $85 \%$ & $93 \%$ & $49 \%$ & $84 \%$ & $86 \%$ & $92 / 123$ \\
\hline
\end{tabular}

${ }^{2}$ Stan na 16.08.2017 r. Obecny skład indeksu został ogłoszony 14.12 .2016 r. Pierwotnie indeks liczył 25 spółek, jednak z dniem 08.06.2017 r. decyzją Zarządu GPW obrót akcjami spółki Pelion S.A. został zawieszony. 


\begin{tabular}{|c|c|c|c|c|c|c|c|}
\hline $\begin{array}{l}\text { ING Bank Śląski } \\
\text { S.A. }\end{array}$ & 2015 & $76 \%$ & $82 \%$ & $51 \%$ & $80 \%$ & $81 \%$ & $87 / 123$ \\
\hline $\begin{array}{l}\text { Bank Millennium } \\
\text { S.A. }\end{array}$ & 2015 & $75 \%$ & $92 \%$ & $25 \%$ & $96 \%$ & $80 \%$ & $94 / 123$ \\
\hline $\begin{array}{l}\text { KGHM Polska } \\
\text { Miedź S.A. }\end{array}$ & 2015 & $87 \%$ & $87 \%$ & $31 \%$ & $57 \%$ & $73 \%$ & $96 / 123$ \\
\hline Bank Pekao S.A. & 2015 & $77 \%$ & $52 \%$ & $35 \%$ & $91 \%$ & $70 \%$ & $76 / 123$ \\
\hline PZU S.A. & 2015 & $38 \%$ & $71 \%$ & $57 \%$ & $65 \%$ & $62 \%$ & $75 / 123$ \\
\hline $\begin{array}{l}\text { Bank Handlowy } \\
\text { w Warszawie S.A. }\end{array}$ & 2016 & $56 \%$ & $72 \%$ & $24 \%$ & $75 \%$ & $61 \%$ & $71 / 123$ \\
\hline PGNiG S.A. & 2015 & $71 \%$ & $46 \%$ & $17 \%$ & $67 \%$ & $50 \%$ & $72 / 123$ \\
\hline PGE S.A. & 2015 & $38 \%$ & $34 \%$ & $51 \%$ & $51 \%$ & $40 \%$ & $98 / 123$ \\
\hline $\begin{array}{l}\text { Tauron Polska } \\
\text { Energia S.A. }\end{array}$ & 2016 & $54 \%$ & $20 \%$ & $6 \%$ & $33 \%$ & $30 \%$ & $86 / 123$ \\
\hline
\end{tabular}

* Transparentność (przejrzystość) to liczba danych branych pod uwagę do oceny przedsiębiorstwa z maksymalnej liczby 123 (118 danych szczegółowych z obszaru środowisko, społeczeństwo, ład organizacyjny, 4 wyniki podsumowujące 4 obszary, 1 wynik końcowy - ocena ważona).

Źródło: opracowanie własne.

Na rysunku 2 przedstawiono graficznie wyniki ESG dla spółek z RESPECT Index zaprezentowane w tabeli 2 .

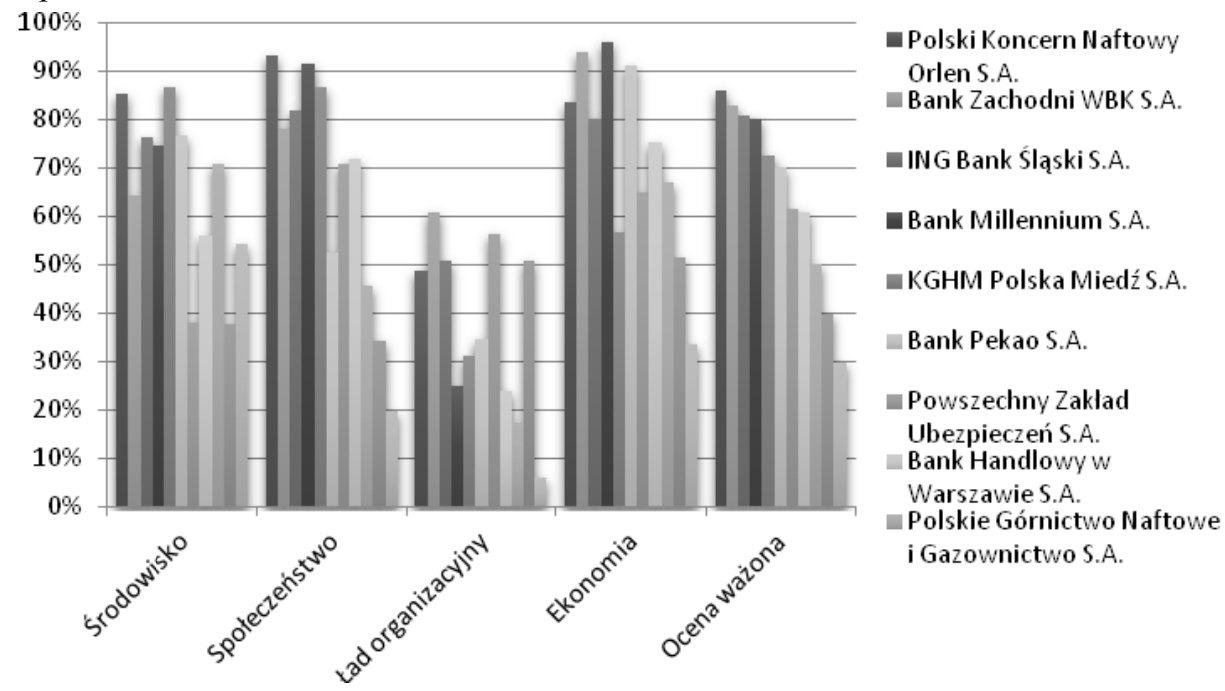

Rysunek 2. Wyniki ESG dla spółek z RESPECT Index na podstawie bazy ASSET4 ESG - wykres dla danych z tabeli 2

Źródło: opracowanie własne.

Szczegółowa analiza danych zawartych w tabeli 2 pozwala stwierdzić, że najlepsze wyniki w obszarze ,środowisko" uzyskały dwie spółki surowcowe: KGHM Polska Miedź S.A. (87\%) i PKN Orlen S.A. (85\%). Taki stan rzeczy nie powinien dziwić, ponieważ podmioty te działają $\mathrm{w}$ sektorach, które mają bardzo istotny wpływ na środowisko naturalne. Dlatego też wysoki poziom zarządzania kwestiami środowiskowymi w tych spółkach wydaje się być rzeczą naturalna̧, ponieważ wszelkie zaniedbania w tym zakresie mogą skutkować nieodwracalnymi szkodami w środowisku naturalnym, a poprzez to 
utratą wizerunku przez te spółki oraz utratą zaufania inwestorów do tych podmiotów. Najgorzej w obszarze ,środowisko” wypadły PGE S.A. i PZU S.A. (38\%), co może świadczyć o tym, że podmioty te nie podejmują istotnych działań środowiskowych, bądź też nie raportuje tych działań lub też raportowane informacje charakteryzuje niska jakość.

W obszarze „społeczeństwo" najlepsze wyniki osiagnęły spółki: PKN Orlen S.A. (93\%) oraz Bank Millenium S.A. (92\%). Najgorzej wypadło przedsiębiorstwo Tauron Polska Energia S.A. (20\%).

Z kolei najlepsze wyniki w obszarze „ład organizacyjny” osiagnęły takie spółki jak: Bank Zachodni WBK S.A. (61\%) i PZU S.A. (57\%). Najgorszy wynik osiagnę̧o ponownie przedsiębiorstwo Tauron Polska Energia S.A. (6\%). Warto w tym miejscu zwrócić uwagę na fakt, że obszar „ład organizacyjny” jest najgorzej realizowanym (bazując na wynikach spółek w tym obszarze) przez badane spółki obszarem spośród czterech analizowanych.

W obszarze ekonomia najlepsze wyniki osiagnęły spółki: Bank Millenium S.A. (96\%) i Bank Zachodni WBK S.A. (94\%). Najgorszy wynik przypadł kolejny raz przedsiębiorstwu Tauron Polska Energia S.A. (33\%).

$\mathrm{W}$ tabelach od 3 do 5 przedstawiono wyniki spółek z RESPECT Index $\mathrm{w}$ poszczególnych obszarach ESG w latach 2011-2016.

Tabela 3. Wyniki w obszarze „środowisko" w latach 2011-2016 dla spółek z RESPECT Index na podstawie bazy ASSET4 ESG

\begin{tabular}{|c|c|c|c|c|c|c|c|}
\hline Spółka & 2011 & 2012 & 2013 & 2014 & 2015 & 2016 & $\begin{array}{c}\text { Zmiana } \\
\text { w stosunku do } \\
\text { roku bazowego }\end{array}$ \\
\hline PKN Orlen S.A. & $63 \%$ & $73 \%$ & $81 \%$ & $77 \%$ & $85 \%$ & b.d. & +22 p.p. \\
\hline $\begin{array}{l}\text { Bank Zachodni WBK } \\
\text { S.A. }\end{array}$ & $11 \%$ & $10 \%$ & $11 \%$ & $10 \%$ & $64 \%$ & b.d. & +53 p.p. \\
\hline ING Bank Śląski S.A. & $32 \%$ & $64 \%$ & $66 \%$ & $69 \%$ & $76 \%$ & b.d. & +44 p.p. \\
\hline Bank Millennium S.A. & $41 \%$ & $73 \%$ & $72 \%$ & $73 \%$ & $75 \%$ & b.d. & +34 p.p. \\
\hline $\begin{array}{l}\text { KGHM Polska Miedź } \\
\text { S.A. }\end{array}$ & $68 \%$ & $62 \%$ & $74 \%$ & $69 \%$ & $87 \%$ & b.d. & +19 p.p. \\
\hline Bank Pekao S.A. & $52 \%$ & $64 \%$ & $67 \%$ & $69 \%$ & $77 \%$ & b.d. & +25 p.p. \\
\hline PZU S.A. & $31 \%$ & $43 \%$ & $35 \%$ & $41 \%$ & $38 \%$ & b.d. & +7 p.p. \\
\hline $\begin{array}{l}\text { Bank Handlowy w } \\
\text { Warszawie S.A. }\end{array}$ & b.d. & $46 \%$ & $41 \%$ & $50 \%$ & $59 \%$ & $56 \%$ & +10 p.p. \\
\hline PGNiG S.A. & $70 \%$ & $67 \%$ & $64 \%$ & $67 \%$ & $71 \%$ & b.d. & +1 p.p. \\
\hline PGE S.A. & $30 \%$ & $25 \%$ & $25 \%$ & $28 \%$ & $38 \%$ & b.d. & +8 p.p. \\
\hline $\begin{array}{l}\text { Tauron Polska Energia } \\
\text { S.A. }\end{array}$ & b.d. & $12 \%$ & $16 \%$ & $18 \%$ & $27 \%$ & $54 \%$ & +42 p.p. \\
\hline
\end{tabular}

Źródło: opracowanie własne. 
Tabela 4. Wyniki w obszarze ,społeczeństwo" w latach 2011-2016 dla spółek z RESPECT Index na podstawie bazy ASSET4 ESG

\begin{tabular}{|l|c|c|c|c|c|c|c|}
\hline \multicolumn{1}{|c|}{ Spółka } & 2011 & 2012 & 2013 & 2014 & 2015 & 2016 & $\begin{array}{c}\text { Zmiana } \\
\text { w stosunku do } \\
\text { roku bazowego }\end{array}$ \\
\hline PKN Orlen S.A. & $75 \%$ & $87 \%$ & $88 \%$ & $89 \%$ & $93 \%$ & b.d. & +18 p.p. \\
Bank Zachodni WBK & $67 \%$ & $57 \%$ & $63 \%$ & $54 \%$ & $78 \%$ & b.d. & +11 p.p. \\
S.A. & $61 \%$ & $82 \%$ & $73 \%$ & $77 \%$ & $82 \%$ & b.d. & +21 p.p. \\
ING Bank Śląski S.A. & $30 \%$ & $84 \%$ & $89 \%$ & $91 \%$ & $92 \%$ & b.d. & +62 p.p. \\
Bank Millennium S.A. & $90 \%$ & $90 \%$ & $89 \%$ & $87 \%$ & $87 \%$ & b.d. & -3 p.p. \\
KGHM Polska Miedź & $52 \%$ & $53 \%$ & $39 \%$ & $43 \%$ & $52 \%$ & b.d. & bez zmian \\
S.A. & $75 \%$ & $86 \%$ & $78 \%$ & $84 \%$ & $71 \%$ & b.d. & -4 p.p. \\
Bank Pekao S.A. & b.d. & $46 \%$ & $47 \%$ & $52 \%$ & $67 \%$ & $72 \%$ & +26 p.p. \\
PZU S.A. & $83 \%$ & $57 \%$ & $59 \%$ & $47 \%$ & $46 \%$ & b.d. & -37 p.p. \\
Bank Handlowy w & $13 \%$ & $11 \%$ & $20 \%$ & $24 \%$ & $34 \%$ & b.d. & +21 p.p. \\
Warszawie S.A. & b.d. & $9 \%$ & $9 \%$ & $10 \%$ & $13 \%$ & $20 \%$ & +11 p.p. \\
PGNiG S.A. & & &
\end{tabular}

Źródło: opracowanie własne.

Tabela 5. Wyniki w obszarze „ład organizacyjny” w latach 2011-2016 dla spółek z RESPECT Index na podstawie bazy ASSET4 ESG

\begin{tabular}{|c|c|c|c|c|c|c|c|}
\hline Spółka & 2011 & 2012 & 2013 & 2014 & 2015 & 2016 & $\begin{array}{c}\text { Zmiana } \\
\text { w stosunku do } \\
\text { roku bazowego }\end{array}$ \\
\hline PKN Orlen S.A. & $62 \%$ & $74 \%$ & $44 \%$ & $42 \%$ & $49 \%$ & b.d. & -13 p.p. \\
\hline $\begin{array}{l}\text { Bank Zachodni WBK } \\
\text { S.A. }\end{array}$ & $17 \%$ & $31 \%$ & $35 \%$ & $50 \%$ & $61 \%$ & b.d. & +44 p.p. \\
\hline ING Bank Śląski S.A. & $35 \%$ & $77 \%$ & $53 \%$ & $75 \%$ & $51 \%$ & b.d. & +16 p.p. \\
\hline Bank Millennium S.A. & $19 \%$ & $26 \%$ & $23 \%$ & $14 \%$ & $25 \%$ & b.d. & +6 p.p. \\
\hline $\begin{array}{l}\text { KGHM Polska Miedź } \\
\text { S.A. }\end{array}$ & $27 \%$ & $24 \%$ & $30 \%$ & $29 \%$ & $31 \%$ & b.d. & +4 p.p. \\
\hline Bank Pekao S.A. & $18 \%$ & $53 \%$ & $40 \%$ & $33 \%$ & $35 \%$ & b.d. & +7 p.p. \\
\hline PZU S.A. & $18 \%$ & $62 \%$ & $50 \%$ & $80 \%$ & $57 \%$ & b.d. & + 39 p.p. \\
\hline $\begin{array}{l}\text { Bank Handlowy w } \\
\text { Warszawie S.A. }\end{array}$ & b.d. & $19 \%$ & $12 \%$ & $20 \%$ & $18 \%$ & $24 \%$ & +5 p.p. \\
\hline PGNiG S.A. & $17 \%$ & $21 \%$ & $22 \%$ & $25 \%$ & $17 \%$ & b.d. & bez zmian \\
\hline PGE S.A. & $25 \%$ & $40 \%$ & $34 \%$ & $44 \%$ & $51 \%$ & b.d. & +26 p.p. \\
\hline $\begin{array}{l}\text { Tauron Polska Energia } \\
\text { S.A. }\end{array}$ & b.d. & b.d. & $5 \%$ & $5 \%$ & $7 \%$ & $6 \%$ & +1 p.p. \\
\hline
\end{tabular}

Źródło: opracowanie własne. 
Analizując dane zawarte w tabeli 3 można stwierdzić, że wszystkie poddane badaniu spółki z indeksu RESPECT, które znajdują się bazie ASSET4 ESG, poczyniły postępy w zarządzaniu czynnikami z obszaru środowiskowego. Największego skoku dokonał Bank Zachodni WBK S.A. - wzrost oceny o 53 punkty procentowe (p.p.), przy czym należy zauważyć, że podmiot ten zaczynał od niskiej oceny w roku bazowym, wynoszącej jedynie $11 \%$. Możemy także zauważyć, że dwa przedsiębiorstwa: PZU S.A. i PGE S.A. nie poczyniły zbyt dużych postępów w zarządzaniu czynnikami środowiskowymi. Pierwsze przedsiębiorstwo w 2011 r. uzyskało wynik równy 31\%, a drugie 30\%. W 2015 r. wynik kształtował się na poziomie $38 \%$ dla obu przedsiębiorstw: przyrost o 7 p.p. dla PZU S.A. i o 8 p.p. dla PGE S.A. Można zatem stwierdzić, że te dwie spółki niewiele zrobiły w przeciagu pięciu analizowanych lat, aby poprawić zarządzanie kwestiami środowiskowymi.

Z kolei analiza danych ujętych w tabeli 4 dotyczących wyników spółek w obszarze społecznym skłania do wyciąnnięcia dwóch wniosków. Po pierwsze, przeważająca większość badanych spółek poprawiła swoje wyniki. Największy wzrost oceny odnotowano w przypadku Banku Millenium S.A. - o 62 p.p. Następne w kolejności znalazły się spółki: Bank Handlowy w Warszawie S.A. - wzrost oceny o 26 p.p. oraz ING Bank Śląski S.A. i PGE S.A. - wzrost o 21 p.p. Warto jednak podkreślić, że spółka PGE S.A. startowała $\mathrm{z}$ niskim wynikiem w roku bazowym, który wyniósł jedynie $13 \%$. Po drugie, mamy do czynienia $\mathrm{z}$ sytuacją, w której trzy spośród analizowanych spółek obniżyły swoje wyniki. W przypadku spółki KGHM Polska Miedź S.A. wynik obniżył się o 3 p.p. (z $90 \%$ do 87\%). Natomiast wynik spółki PZU S.A. obniżył się o 4 p.p. (z $75 \%$ do $71 \%$ ). Biorąc jednak pod uwage wysoką - w przypadku pierwszej spółki, oraz dość wysoką - w przypadku drugiej spółki, wartość oceny w roku bazowym, odnotowane niewielkie spadki nie powinny budzić dużego niepokoju. Inaczej sytuacja wygląda w przypadku spółki PGNiG S.A., której wynik obniżył się aż o 37 p.p. (z 83\% do 46\%). Tak duża redukcja wyniku może świadczyć o istotnych problemach przedsiębiorstwa $\mathrm{W}$ zarządzaniu czynnikami społecznymi.

Na koniec pogłębionej analizy należy odnieść się do wyników spółek w obszarze ładu organizacyjnego. Jak pokazują dane zawarte $\mathrm{W}$ tabeli 5 dziewięć $\mathrm{z}$ jedenastu analizowanych spółek poprawiło swoje wyniki, jedna odnotowała spadek wyniku, a jedna utrzymała wynik. Co warte również podkreślenia siedem spośród analizowanych spółek uzyskało bardzo niski wynik (poniżej 20\%) w roku bazowym. Mając powyższe na uwadze należy zauważyć, że przy tak niskiej wartości bazowej duża część przedsiębiorstw poczyniła niewielkie postępy w zarządzaniu i raportowaniu czynników z obszaru ładu organizacyjnego: pięć spółek odnotowało wzrost oceny w przedziale od 1 p.p. do 7 p.p., a jeden podmiot nie zmienił swojego wyniku w porównaniu z rokiem bazowym. Najwyższy wzrost wyniku osiągnął Bank Zachodni WBK S.A. - o 44 p.p. (z 17\% do 61\%). Następnie spółki: PZU S.A. - o 39 p.p. (z 18\% do 57\%) oraz PGE S.A. - o 26 p.p. (z 25\% do 51\%). Natomiast największy spadek wyniku odnotowała spółka PKN Orlen S.A. - o 13 p.p. (z $62 \%$ do $49 \%$ ).

Podsumowując przeprowadzoną powyżej analizę trzech obszarów ESG należy stwierdzić, że spółki z indeksu RESPECT nagorzej radzą sobie w dziedzinie zarządzania czynnikami ładu organizacyjnego.

W tabeli 6 przedstawiono podsumowanie statystyczne wyników ESG dla analizowanych spółek wchodzących w skład X edycji RESPECT Index. 
Tabela 6. Podsumowanie statystyczne wyników ESG dla spółek z RESPECT Index na podstawie bazy ASSET4 ESG za rok 2015(2016)

\begin{tabular}{|l|c|c|c|c|c|c|}
\hline \multicolumn{1}{|c|}{ Wyszzzególnienie } & Środowisko & $\begin{array}{c}\text { Społeczeń } \\
\text {-stwo }\end{array}$ & $\begin{array}{c}\text { Lad organiza- } \\
\text { cyjny }\end{array}$ & Ekonomia & $\begin{array}{c}\text { Ocena } \\
\text { ważona }\end{array}$ & $\begin{array}{c}\text { Transpa- } \\
\text { rentność }\end{array}$ \\
\hline Średnie wartości & $66 \%$ & $66 \%$ & $37 \%$ & $72 \%$ & $65 \%$ & 85 \\
\hline Mediana & $71 \%$ & $72 \%$ & $35 \%$ & $75 \%$ & $70 \%$ & 87 \\
\hline Wartość maksymalna & $87 \%$ & $93 \%$ & $61 \%$ & $96 \%$ & $86 \%$ & 98 \\
\hline Wartość minimalna & $38 \%$ & $20 \%$ & $6 \%$ & $33 \%$ & $30 \%$ & 71 \\
\hline $\begin{array}{l}\text { Różnica między } \\
\text { maksymalną a } \\
\text { minimalną wartością }\end{array}$ & 49 p.p. & 73 p.p. & 55 p.p. & 63 p.p. & 56 p.p. & 27 \\
\hline
\end{tabular}

Źródło: opracowanie własne.

Analizując dane zawarte w tabelach 2 i 6 można stwierdzić, że najlepszy wynik ESG uzyskał PKN Orlen S.A. z oceną ważoną równą $86 \%$, podczas gdy najgorszy wynik - 30\%, uzyskał Tauron Polska Energia S.A. Różnica 56 p.p. między najlepszym a najgorszym wynikiem wskazuje na bardzo duże rozbieżności w ocenie danych ESG spółek z RESPECT Index. Ocenę ważoną powyżej 50\% uzyskało osiem spółek, a średni wynik dla wszystkich spółek to $65 \%$. Można zatem stwierdzić, że uzyskany wynik dla spółek z indeksu RESPECT nie jest wysoki.

Przyglądając się poszczególnym obszarom danych ESG należy zwrócić uwagę, że średnia wartość ocen z obszaru ,ład organizacyjny” jest zaskakująco niska i wynosi tylko $37 \%$. W tym obszarze zaobserwowano też najniższą wartość wynoszącą $6 \%$ dla Tauron Polska Energia S.A. Tymczasem w jednym z rankingów (Ranking Odpowiedzialnych Firm 2015) spółka uzyskała III miejsce w sektorze paliw, energetyki i wydobycia, co budzi pewne wattpliwości w aspekcie bardzo słabego rezultatu jaki uzyskała na podstawie danych ASSET4 ESG (wartość równa 30\%).

O niskim poziomie ocen przedsiębiorstw $\mathrm{z}$ indeksu RESPECT $\mathrm{w}$ obszarze ,tad organizacyjny" świadczą także wyniki badań przeprowadzonych przez autorów niniejszego opracowania na całej populacji spółek wchodzących w skład X edycji przedmiotowego indeksu. Okazało się bowiem, że zakres tematyczny raportów niefinansowych tych spółek odbiegał od oczekiwanego poziomu. Kompletność ujawnień przebadanych spółek z indeksu RESPECT oceniono na 44\%. Stan raportowania informacji niefinansowych cechował się stosunkowo słabym poziom ujawnień ekonomicznych, których poziom oszacowano na $34 \%$. Na poziomie $35 \%$ kształtował się poziom ujawnień zarówno środowiskowych, jak i społecznych. Natomiast informacje dotyczące ładu organizacyjnego ujawniane są jedynie na zatrważająco niskim poziomie oszacowanym na 6\% [Sikacz, Wołczek 2017].

Odnosząc się do wyników zaprezentowanych w tabeli 6, należy stwierdzić, że średni wynik w obszarze dotyczącym środowiska to $66 \%$, społeczeństwa natomiast $66 \%$, a ekonomii to $72 \%$. Różnica wynosząca między najlepszym a najgorszym wynikiem w obszarze środowisko 49 p.p., społeczeństwo 73 p.p., ład organizacyjny 55 p.p., a w obszarze ekonomia 63 p.p. świadczy o bardzo dużych rozbieżnościach między wynikami spółek, mimo że po spółkach mających spełniać najwyższe standardy związane $\mathrm{z}$ odpowiedzialnością można było spodziewać się dużo mniejszych różnic i o wile lepszych rezultatów. 


\section{Podsumowanie i wnioski}

Zaprezentowana analiza wyników ESG uzyskanych przez spółki wchodzące w skład indeksu RESPECT wskazuje na duże różnice w wynikach między danymi podmiotami. Należy zwrócić uwagę na problem nieuwzględniania wyników ESG dostępnych w renomowanych bazach danych w doborze spółek do przedmiotowego indeksu spółek społecznie odpowiedzialnych. Badania wskazują na to, że można mieć wątpliwości co do doboru spółek do indeksu RESPECT, jak i wyników różnego rodzaju konkursów przedsiębiorstw odpowiedzialnych społecznie. W związku z powyższym szeroko rozumianym interesariuszom zaleca się sięganie po dodatkowe źródła informacji niefinansowych o przedsiębiorstwach, takich jak baza danych ASSET4 ESG, celem nabrania pewności, ewentualnie rozwiania wątpliwości co do podejmowanych decyzji, na przykład inwestycyjnych. Działania przedsiębiorstw w obszarach ESG, jak i efekty tych działań, zaczynają bowiem odgrywać coraz większe znaczenie we współczesnej gospodarce.

Niniejsze opracowanie dotyczy indeksu RESPECT, funkcjonującego w ramach polskiej Giełdy Papierów Wartościowych w Warszawie S.A., która jednocześnie wchodzi w skład tego indeksu. Dalsze badania można poszerzyć o analizę wyników ESG spółek uczestniczących w innych światowych indeksach spółek społecznie odpowiedzianych.

\section{Literatura}

Bassen A., Meyer K., Schlange J., The influence of corporate responsibility on the cost of capital, 2006, http://ssrn.com/abstract=984406 (24.08.2017).

Burke L., Logsdon J.M., How corporate social responsibility pays off, Long Range Planning, vol. 29, 1996, s. 495-502.

Domańska-Szaruga B., Rola czynników ESG w budowaniu wartości przedsiębiorstwa, Współczesne Zarządzanie / Contemporary Management Quarterly nr 4, 2011, s. 141-151.

Jędrzejka D., Ujawnienia ESG polskich spótek giełdowych w świetle wyników badań, Studia Ekonomiczne, nr 186 cz. 2, 2014, s. 13-26.

Kaputa J., Raportowanie zrównoważonego rozwoju jako wyzwanie dla przedsiębiorstw XXI wieku, Zarządzanie i Finanse, 2013, s. 113-127.

Knox S., Maklan S., Corporate Social Responsibility: moving beyond investment towards measuring outcomes, European Management Journal, vol. 22, no. 5, 2004, s. 23-35.

Maignan I., Ferrell O.C., Antecedents and benefits of corporate citizenship: an investigation of french businesses, Journal of Business Research, vol. 51, 2001, s. 37-51.

Marcinkowska M., Odpowiedzialne przedsiebiorstwo na rynku kapitałowym - czyli o giełdowych indeksach zrównoważonego rozwoju, w: J. Duraj (red.), Przedsiębiorstwo na rynku kapitałowym, Wyd. UŁ, Łódź, 2010, s. $123-144$.

Ocena Tomo LLC, Annual Study of Intangible Asset Market Value, 2015,

http://www.oceantomo.com/2015/03/04/2015-intangible-asset-market-value-study/ (24.08.2017).

Ranking Odpowiedzialnych Firm 2015, https://grupa.tauron.pl/tauron/TAURON-dla-

otoczenia/Strony/nagrody-i-wyroznienia.aspx (24.08.2017).

Ribando J.M., G. Bonne G., A new quality factor: finding alpha with ASSET4 ESG data, Thomson Reuter, Starmine Research Note, 2010,

http://citeseerx.ist.psu.edu/viewdoc/download?doi=10.1.1.429.577\&rep=rep1\&type=pdf (24.08.2017).

Sikacz H., Wołczek P., Analiza raportów informacji niefinansowych spótek z RESPECT Index, Marketing i

Rynek nr 11, 2017, s. 540-552

Sroka R. (red.), Analiza ESG spółek w Polsce, Stowarzyszenie Emitentów Giełdowych, Warszawa, 2012.

Sroka R. (red.), Analiza ESG spółek w Polsce, Stowarzyszenie Emitentów Giełdowych, Warszawa, 2014.

Sroka R. (red.), Analiza ESG spółek w Polsce, Stowarzyszenie Emitentów Giełdowych, Warszawa, 2016. 
Thomson Reuters, ASSET4 ESG Data, 2012a,

https:/www.thomsonreuters.com/content/dam/openweb/documents/pdf/tr-com-financial/fact-sheet/esg-datafact-sheet.pdf (24.08.2017).

Thomson Reuters, Thomson Reuters Datastream ASSET4 EEG Content, 2012b,

http://repository.ubvu.vu.nl/datacentrum/ASSET4_ESG_Datastream.pdf (24.08.2017).

\section{Summary}

This study is concerned with the analysis of non-financial data related to environmental issues, social responsibility and corporate governance, called ESG data (Environmental, Social, Governance). The companies from the RESPECT Index are the subject of analysis. This suggesting that their ESG results should be high due to their affiliation to the mentioned index. Therefore the purpose of this paper is to verify the view on the high ESG results the companies from the RESPECT Index. To make analysiss the data from the ASSET4 ESG database were used. This database is owned by Thomson Reuters, one of the world's major information providers, both for businesses, professionals, and researchers. The analysis of the ESG results obtained by the companies from the RESPECT Index shows that there are big differences in results between the entities, although from the companies, which should meet the highest standards of responsibility, we could expect smaller differences and better results.

Keywords: ESG factors, RESPECT Index, ASSET4 ESG, ESG databases

Informacja o autorach:

dr inż. Hanna Sikacz

Uniwersytet Ekonomiczny we Wrocławiu

Wydział Inżynieryjno-Ekonomiczny

Katedra Pracy i Kapitału

e-mail: hanna.sikacz@ue.wroc.pl

dr Przemyslaw Wolczek

Uniwersytet Ekonomiczny we Wrocławiu

Wydział Nauk Ekonomicznych

Katedra Zarządzania Strategicznego

e-mail: przemyslaw.wolczek@ue.wroc.pl 